\title{
New journal for the worldwide regional science movement
}

\author{
David A. Plane ${ }^{1,2}$
}

Published online: 31 January 2017

(C) The Japan Section of the Regional Science Association International 2017

Births are always exceedingly exciting events! Especially, when a child is brought into one's own immediate family. As someone who was honored during the course of my career to have had the opportunity to edit both "grand-daddy" journals of our field, the Journal of Regional Science and Papers in Regional Science: the journal of the Regional Science Association International (RSAI), I have intimate knowledge of how much effort and careful thought will be required to raise this treasured infant to adulthood. I also know the satisfaction that the multiple parents of this venture-its father, Professor Yoshiro Higano, foremost among them-will gain from nurturing this latest regional science offspring of theirs and from watching it blossom into maturity. It is my fond wish that Asia-Pacific Journal of Regional Science grows up to become a top outlet for regional science research: one consistently publishing innovative research of global reach and significance.

Recent decades have witnessed a high birth rate of journals. This trend cuts across many scientific disciplines; it is even more pronounced in cutting-edge interdisciplinary fields. The stable of regional science journals is rapidly expanding; the number of new entrants into the world of analytically oriented regional research is cause for celebration. But just as when economies develop and there is a need for a wider range and greater specialization of industries, so too with the maturation of an academic field it behooves those launching journals to develop strong, specialized brands and to endeavor to serve expanding markets. Moreover, now only in its nascence, Asia-Pacific Journal of Regional Science represents the coming of age of significant movements both within our multidisciplinary field and in the broader context of our globalizing planet. It is now the job of the editorial team to begin working on securing a strong reputation and niche for this new

David A. Plane

plane@email.arizona.edu

1 School of Geography and Development, University of Arizona, Tucson, AZ, USA

2 Western Regional Science Association, Tucson, AZ, USA 
journal. I have faith in their abilities to do so, and there is no question that the journal can leverage an expanding market.

Perhaps no other region has seen such a recent explosion of interest in regional science as the Asia-Pacific. The Pacific Regional Science Conference Organization (PRSCO) was founded in 1968 as a joint enterprise of the Japan Section of the Regional Science Association (JSRSA) and the Western Regional Science Association. The first meeting of the new organization occurred at the East-West Center of the University of Hawaii, August 26-29, 1969. Since then, regional science has diffused across Asia and all around the Pacific Rim: early on in Australasia, more recently farther down the extensive Pacific Coast of the Americas. Thanks in large measure to the leadership of the Japan Section and WRSA, and in particular to the boundless energies of Professor Yoshiro Higano and his predecessor, Professor Hirotada Kohno, PRSCO now boasts some 14 member organizations. And during this time span, probably no other region has experienced the magnitude of changes attendant to all facets of human life brought about by the globalization of the world's space-economy.

So, this new-born journal is cradled in a region of key significance for the worldwide regional science movement: one where there is a huge, expanding pool of highly trained scholars and practitioners of regional science, and one where the field's sophisticated analytical tools and studies are critically needed to contribute to critical, pressing policy concerns. This journal is a child born to great advantage, but one that, concomitantly, will have to face up to the pressures of great expectations. I join with colleagues from far and wide in adding my sincere wish for a long and productive life for Asia-Pacific Journal of Regional Science, and for the successful achievement of its vast potential. 